\title{
"An empirical study of the real effective exchange rate and foreign direct investment in Vietnam"
}

Tram Thi Xuan Huong (D https://orcid.org/0000-0002-6955-1527
My-Linh Thi Nguyen (D https://orcid.org/0000-0001-7475-2502
Nguyen Thi Kim Lien (D https://orcid.org/0000-0002-7562-0381

\begin{tabular}{ll} 
ARTICLE INFO & $\begin{array}{l}\text { empirical study of the real effective exchange rate and foreign direct investment } \\
\text { in Vietnam. Investment Management and Financial Innovations, 17(4), 1-13. } \\
\text { doi:10.21511/imfi.17(4).2020.01 }\end{array}$ \\
\hline DOI & http://dx.doi.org/10.21511/imfi.17(4).2020.01 \\
\hline RELEASED ON & Monday, 26 October 2020 \\
\hline RECEIVED ON & Monday, 20 July 2020 \\
\hline ACCEPTED ON & Thursday, 08 October 2020 \\
\hline LICENSE & (oc) EY \\
\hline JOURNAL & License \\
\hline ISSN PRINT & "Investment Management and Financial Innovations" \\
\hline ISSN ONLINE & $1810-4967$ \\
\hline PUBLISHER & $1812-9358$ \\
\hline FOUNDER & LLC “Consulting Publishing Company "Business Perspectives" \\
\hline
\end{tabular}

$\begin{array}{ccc}8 & 5 & 0 \\ \text { NUMBER OF REFERENCES } & \text { NUMBER OF FIGURES } & \text { NUMBER OF TABLES } \\ \mathbf{4 0} & \mathbf{3} & \mathbf{6}\end{array}$

(c) The author(s) 2021. This publication is an open access article. 


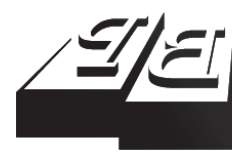

BUSINESS PERSPECTIVES

(O)

LLC "CPC "Business Perspectives" Hryhorii Skovoroda lane, 10, Sumy, 40022, Ukraine www.businessperspectives.org
Received on: $20^{\text {th }}$ of July, 2020 Accepted on: $8^{\text {th }}$ of October, 2020 Published on: $26^{\text {th }}$ of October, 2020

(c) Tram Thi Xuan Huong, My-Linh Thi Nguyen, Nguyen Thi Kim Lien, 2020

Tram Thi Xuan Huong, Ph.D., Associate Professor, University of Economics Ho Chi Minh City, Vietnam.

My-Linh Thi Nguyen, Ph.D., Associate Professor, University of Finance Marketing, Vietnam.

Nguyen Thi Kim Lien, MA, Lecturer, Industrial University of Ho Chi Minh City, Vietnam. (Corresponding author)

This is an Open Access article, distributed under the terms of the Creative Commons Attribution 4.0 International license, which permits unrestricted re-use, distribution, and reproduction in any medium, provided the original work is properly cited.

Conflict of interest statement: Author(s) reported no conflict of interest
Tram Thi Xuan Huong (Vietnam), My-Linh Thi Nguyen (Vietnam), Nguyen Thi Kim Lien (Vietnam)

\section{AN EMPIRICAL STUDY OF THE REAL EFFECTIVE EXCHANGE RATE AND FOREIGN DIRECT INVESTMENT IN VIETNAM}

\begin{abstract}
Foreign direct investment (FDI) inflows to Vietnam have increased significantly in recent years. Theoretically, capital inflows will put pressure on the overvaluation of local currencies in countries, despite different exchange rate mechanisms. So, the problem facing the Vietnamese government is the need to examine the relationship between the exchange rate and FDI in order to develop effective policies. This study examined the relationship between the exchange rate and FDI in Vietnam in the period of 2005-2019 using the VAR (vector autoregression) model based on quarterly frequency data. The new points of this study are: (i) using the real effective exchange rate (REER) of the Vietnamese currency with 143 major trading partners of Vietnam; and (ii) adding two control variables into the VAR model to examine the relationship between the exchange rate and FDI in Vietnam - a case study for developing countries. The findings show that, firstly, there is a positive causal relationship between FDI and Vietnam's real effective exchange rate. Secondly, trade openness has a positive impact on FDI and REER in Vietnam. Thirdly, economic growth has an impact on REER, but no statistically significant impact on FDI was found. The findings can provide useful information to help policymakers plan and make decisions on future policies and support further research studies.
\end{abstract}

\section{Keywords $\quad$ FDI, REER, Granger causality, VAR, Vietnam}

JEL Classification E22, F21, F31

\section{INTRODUCTION}

According to Barrell and Pain (1997), Borensztein et al. (1998), FDI is a capital source that plays an important role in promoting productivity growth in both developed and developing countries. In particular, for developing countries, FDI is seen as a valuable additional source of domestic savings. On the other hand, when FDI enterprises invest in a country, they also help transfer technology, create jobs, and train workers for knowledge and skills. These benefits reinforce the importance of FDI.

Over the past decades, many studies around the world have been conducted to assess the relationship of exchange rates and FDI inflows. Overall, existing studies provide evidence that a relationship exists between these two variables (Froot \& Stein, 1991; Blonigen, 1997; Takagi \& Shi, 2011; Boateng et al., 2015; Djulius, 2017). However, studies are still controversial about the direction of the impact between FDI and the exchange rate. On the other hand, the studies show that the characteristics of the relationship between these two variables may differ due to the characteristics of the research data, the research model and the exchange rate regime in each country. 
In the process of global integration, foreign direct investment (FDI) is becoming more and more important for Vietnam, a developing country. According to the General Statistics Office of Vietnam (2018), the foreign direct investment sector accounts for approximately $20 \%$ of gross domestic product (GDP), with the contribution increasing over the years. The FDI sectors help to improve Vietnam's export capacity, becoming a bridge for Vietnam to quickly approach and cooperate with many countries, step by step raising the position and strength of Vietnam in the globalization context. Exports from the FDI sector averaged over 66\% of Vietnam's total merchandise exports in the 2011-2016 period (General Statistics Office of Vietnam, 2018).

For many years, Vietnam has been known as a developing country with a relatively high growth rate and a stable exchange rate, increasing trade openness. These features have contributed to consolidating Vietnam's image as an attractive destination for foreign investors. As a result, FDI inflows to Vietnam have increased significantly in recent years. Theoretically, capital inflows will put pressure on the overvaluation of local currencies in countries, despite different exchange rate mechanisms. In a flexible exchange rate regime, an increase in the real value of the local currency occurs through an increase in the nominal value of the local currency. Meanwhile, in a fixed exchange rate regime, an increase in the real value of the local currency is mainly driven by higher prices for non-commercial goods.

Vietnam is a country that is pursuing a mixed exchange rate mechanism. Therefore, the appreciation of VND depends on both processes: an increase in the nominal value of the local currency and an increase in the price of non-commercial goods. The issue to be concerned about is how FDI inflows to Vietnam are related to the exchange rate, from which appropriate policies can be proposed to improve the efficiency of FDI inflows. However, studies on the relationship between the exchange rate and FDI in Vietnam are still limited in number and focus on one-way impacts of the exchange rate on FDI (Pham \& Nguyen, 2013). Therefore, this study attempts to contribute to the current research gap. This paper provides the empirical evidence on the two-way relationship between the exchange rate and FDI with the following key points: (1) using the real effective exchange rate variable in Vietnam (REER) with a large number of trading partners (including 143 partner countries); and (2) considering the impact of trade openness and economic growth as control variables in the VAR model of the relationship between REER and FDI in Vietnam.

\section{LITERATURE REVIEW}

\subsection{Theoretical approaches}

According to Cushman (1985), for market-oriented FDI (mainly using input resources from the home country to produce and sell products in the host country), the depreciation of the host country's currency will cause profits to be transferred back to the home country become low, discouraging investors and decreasing FDI. However, if cost-driven FDI mainly uses the input resources of the host country to produce and then sell products to the home country or export to a third country, the depreciation of the recipient country's currency will cause production costs of FDI enterprises reduce, creating an advantage for exports, thereby promoting FDI.

Dunning (1988) introduces the OLI (Ownership, Location, Internalization) model that states that the motive for offshore investment of multinational companies is that they possess certain advantages in terms of ownership, and location and localization enable them to compete with domestic enterprises in the host countries' market. Dunning's OLI model (1988) emphasizes the direct role of real exchange rates for FDI arguing that one driving force for FDI is that multinational companies want to move to lower cost locations (including costs related to exchange rates). Dunning (1988) argued that investment decisions of companies that want to own income-generating assets abroad tend to be influenced by financial and exchange rate variables.

The theory of market imperfections states that markets with imperfections make business inefficient. Meanwhile, businesses will implement direct investment abroad to promote business activities and overcome those imperfect factors. Two 
theories that analyze the effects of exchange rates on imperfect markets have a great influence on the theoretical approach to the relationship between the exchange rate and FDI later: Froot and Stein (1991) and Blonigen (1997). Froot and Stein (1991) argue that the relationship between exchange rates and FDI is due to market imperfections. A change in the exchange rate would increase the financial value of companies holding denominated assets in a currency that would increase in value versus firms holding denominated assets in currency that would decrease in value. When the other conditions are constant, the value of the recipient country's currency is inversely proportional to the FDI in that country. Blonigen (1997) further emphasized that exchange rates have the greatest impact on FDI acquisitions of high technology industries (industries in which special assets of enterprises are of significant importance).

However, using a theoretical approach based on expanded production, Campa (1993) suggests that exchange rates may influence future profit expectations. Therefore, the depreciation of the recipient country's currency may weaken FDI inflows into that country.

Itagaki (1981) makes another argument based on the purchasing power parity (PPP) theory of Gustav Cassel (1920). According to Itagaki (1981), if PPP theory really exists, foreign companies will not have any risks related to exchange rates because the exchange rate changes will be offset by changes in the relative price among countries. However, the conclusion by Itagaki (1981) remains controversial as to whether PPP holds even in the long run, let alone at all points in time and for relative price levels in all industries.

\subsection{Causality one-way runs from the exchange rate to FDI}

\subsubsection{A negative effect of the exchange rate on FDI}

Takagi and Shi (2011) measure the impact of exchange rate levels and other macro variables on Japanese FDI in some Asian countries, such as China, Indonesia, Malaysia, Philippines, South Korea and Thailand, for the period of 1987-2008. Research results show that the exchange rate has a negative impact on FDI.
The research by Pham and Nguyen (2013) on the relationship between the level of the real exchange rate and FDI in Vietnam in the period 1990-2007 also shows that the depreciation of the VND has motivated an increase in FDI inflows during this period. Ibrahim and Raji (2018) show that the real exchange rate has a significant negative impact on the merger and acquisition decisions of foreign investors in ASEAN countries.

\subsubsection{A positive effect of the exchange rate on FDI}

Buch and Kleinert (2008) investigated German FDI to many different countries in the world, for the period 1997-2002. The results show that the value of the domestic currency has attracted German FDI into these countries. At the same time, results of Alba et al. (2010) showed that, the exchange rate had a statistically significant positive effect on the average rate of FDI inflows to the United States from 1982 to 1994. Specifically, FDI capital inflows to the US wholesale trade sector increased due to the appreciation of the US dollar.

Boateng et al. (2015) used quarterly data to assess the impact of macroeconomic factors on FDI into Norway in 1986-2009. The study found that the exchange rate has a statistically significant impact on FDI inflows to Norway. The appreciation of the NOK has encouraged FDI inflows in Norway during this period.

Djulius (2017) studied the determinants of FDI in Indonesia from 1981 to 2015. The research results show that the exchange rate has a positive impact on FDI. Besides, the study of Burakov, Intse, and Freidin (2018) related to FDI in Russia and Belarus in the period 1997-2017 shows that exchange rate appreciation positively affects FDI inflows to these countries.

\subsection{Causality one-way runs from FDI to the exchange rate}

Morande (1988) showed that capital inflows have a causal relationship with the real exchange rate, particularly that capital inflows tend to appreciate the host country's currency. The study found that the sudden disruption of capital flows in late 1981 resulted in a real depreciation of the peso from June to August 1982. 
Ibarra (2011) analyzes the determinants of the exchange rate in Mexico from 1988 to 2008. In terms of controlling other factors that affect exchange rates, the study shows that all types of capital flows tend to appreciate peso. In particular, FDI inflows were found to significantly increase the real exchange rate. Similarly, Jongwanich and Kohpaiboon (2013) and Tsaurai (2015) also show that FDI inflows have an impact on real exchange rates.

Aizenman and Binici (2016) reveal that external factors play an important role in exchange rates for both groups of countries: OECD countries and emerging countries. The research results have found that FDI inflows have a significant impact on exchange rates in emerging market economies.

\subsection{Two-way relationship between exchange rates and FDI}

Kosteletou and Liargovas (2000) consider the relationship between foreign direct investment and real exchange rates in the United States, Japan and 12 European countries: Belgium, Luxembourg, Denmark, France, Germany, Greece, Ireland, Italy, Netherlands, Portugal, Spain, UK, for the 1960-1997 period. The study shows that there is a causal relationship between the real exchange rate and FDI in large countries with freely floating currencies, such as the United States, the United Kingdom and Japan. In other countries in the sample, small countries with an almost fixed exchange rate mechanism, there exists causality running in both ways between the exchange rate and FDI. The results show that the exchange rate and FDI relations differ among countries.

Tsaurai (2015) finds that there is a causal relationship between (1) South African rand value and FDI in the long run, and (2) FDI and the rand value only in the short run in South Africa. FDI flows into South Africa also play a role in stabilizing the value of the rand. Similarly, Lee (2015) shows that there exists a significant relationship between exchange rate and FDI flows in Korea. Similarly, Shrikhande (2002) and Lee (2015) emphasize that there is a significant relationship between exchange rates and FDI inflows.

\subsection{No statistically significant relationship was found between exchange rates and FDI inflows}

Yang et al. (2000) studied the relationship between exchange rates and FDI in Australia between 1985 and 2000. The results have not found a statistically significant impact of the level of exchange rates on FDI in Australia in the short term. Abdullah et al. (2006) identify factors affecting FDI inflows into China from five ASEAN countries, namely Malaysia, Thailand, Philippines, Indonesia and Singapore in the 1990s. The results have not detected any statistical significant evidence on the impact of exchange rates on FDI. Similarly, Vita and Abbott (2007) did not find a statistically significant impact of the level of exchange rates on UK FDI originating from seven major countries in the period of 1975-2001.

Polat and Payaslığlu (2016) used monthly data for the period 2004-2014 with the Markov conversion model to test the impact of the real exchange rate (RER) on FDI inflows into Turkey, using a set of control variables. The research results have not found a statistically significant effect of the level of exchange rates on FDI.

Ersoy (2013) evaluated the role of foreign investment flows to the exchange rate in Turkey in the period from January 1992 to September 2007. The results show that FDI has a negative but not statistically significant effect on the exchange rate in Turkey. Ifeakachukwu and Ditimi (2014) studied the relationship between foreign investment and exchange rates in Nigeria during the period of 1986-2011. The research results did not find a causal relationship between FDI inflows and exchange rates during this period. Similarly, the study of Aizenman and Binici (2016) could not prove/confirm that FDI had a statistically significant impact on exchange rates in OECD countries.

\subsection{Impact of trade openness and economic growth on the relationship between REER and FDI}

Previous studies show that, in addition to the twoway relationship between the two variables, exchange rates and FDI inflows are also influenced by other 
macroeconomic factors such as economic growth and trade openness. In general, the studies suggest that economic growth has a positive impact on capital flows, while at the same time leading to the longterm appreciation of the domestic currency. Studies using economic growth variables to analyze the relationship between exchange rates and FDI have found a statistically significant impact of economic growth on exchange rates and FDI inflow (Komuves \& Ramirez, 2014; Ahmed, 2018; Burakov et al., 2018). Asiedu (2002) argues that trade openness provides certain advantages to exporting countries by eliminating tariff barriers and increasing transnational mobility in capital and labor. The large trade openness makes it easier for foreign investors to import the input supplies necessary for production activities, and to easily export manufactured products. Several studies, using the trade openness variable to explore the relationship between exchange rate and foreign investment, have found a statistically significant impact of trade openness on exchange rates and FDI (Djulius, 2017; Burakov et al., 2018).

In general, the relationship between exchange rates and FDI is a problem that has been of great interest in many countries. Research results on this issue are quite diverse, indicating many research gaps. First, most studies agree that there is a relationship between exchange rates and FDI, while some studies have not found statistically significant evidence. Secondly, studies on the relationship between exchange rates and FDI have been carried out in developed countries, while in emerging markets, they are limited in number and only encompass the recent decades. Thirdly, the characteristics of the research country and the research period significantly affect the research results. Vietnam is a developing country, trying to reform policies (including the exchange rate regime) to attract FDI inflows, but research in this field is limited in number and in the absence of quantitative research. Therefore, this study has been conducted to fill the gap in research on the relationship between exchange rates and FDI in Vietnam, a case study for emerging countries.

\section{METHODOLOGY}

Based on previous studies, such as Mo (1988), Kodongo and Ojah (2013), Komuves and Ramirez (2014), Ifeakachukwu and Ditimi (2014), Lee (2015) and Boateng et al. (2015), a research model was set up to test the relationship between exchange rates and FDI in Vietnam:

$$
\begin{aligned}
& F D I_{t}=\alpha_{0}+\sum_{j=1}^{n} \alpha_{1 j} F_{t-j}+ \\
& +\sum_{j=1}^{n} \alpha_{2 j} \text { REER }_{t-j}+ \\
& +\sum_{j=1}^{n} \alpha_{3 j} \text { OPEN }_{t-j}+ \\
& +\sum_{j=1}^{n} \alpha_{4 j} \text { GROWTH }_{t-j}+\varepsilon_{t}, \\
& R E E R_{t}=\beta_{0}+\sum_{j=1}^{n} \beta_{1 j} R \operatorname{RER}_{t-j}+ \\
& +\sum_{j=1}^{n} \beta_{2 j} \text { FDI }_{t-j}+\sum_{j=1}^{n} \alpha_{3 j} \text { OPEN }_{t-j}+ \\
& +\sum_{j=1}^{n} \alpha_{4 j} \text { GROWTH }_{t-j}+\varepsilon_{t},
\end{aligned}
$$

where $F D I_{t}$ is Foreign Direct Investment in Vietnam (million USD), $F D I_{t-j}$ is a lagged variable of the Foreign Direct Investment variable; REER $R_{t}$ is the real effective exchange rate of Vietnam with 143 major trading partners, $R E E R_{t-j}$ is a lagged variable of the real effective exchange rate variable.

Control variables: OPEN is trade openness (\%); GROWTH is economic growth (\%).

All variables are collected for the period of 2005:Q4 to 2019:Q3 (quarterly frequency). Data on the real effective exchange rate of the Vietnamese currency with 143 major trading partners of Vietnam are obtained from the Bruegel (Europe). An increased REER means the local currency is depreciating, and vice versa, if REER falls, it means the local currency is appreciating.

The data of FDI inflows into Vietnam are obtained from the International Financial Statistics (IFS) of the IMF database. Variables of growth and openness are obtained and calculated based on data from the General Statistics Office of Vietnam (see Table 1). 
Table 1. Variables used in the research model

Source: Authors' analysis results.

\begin{tabular}{|c|c|c|c|c|}
\hline Variable & Description & Variable measurement & Data source & Previous study \\
\hline REER & $\begin{array}{l}\text { Real effective } \\
\text { exchange rate }\end{array}$ & $\begin{array}{l}\text { Real effective exchange rate of } \\
\text { the Vietnamese currency with } \\
143 \text { major trading partners of } \\
\text { Vietnam (quarterly frequency) }\end{array}$ & Bruegel (EUROPE) & $\begin{array}{l}\text { Combes et al. (2012); Ersoy (2013); } \\
\text { Komuves \& Ramirez (2014); Linh \& Lien } \\
\text { (2020) }\end{array}$ \\
\hline FDI & FDI inflow & $\begin{array}{l}\text { FDI inflows to Vietnam (quarterly } \\
\text { frequency) }\end{array}$ & $\begin{array}{c}\text { International } \\
\text { Financial Statistics } \\
\text { (IFS) }\end{array}$ & $\begin{array}{l}\text { Cushman (1985); Dunning (1988); Froot } \\
\text { \& Stein (1991); Campa (1993); Blonigen } \\
\text { (1997); Asiedu (2002); Abdullah et al. } \\
\text { (2006); Takagi \& Shi (2011); Pham \& } \\
\text { Nguyen (2013); Boateng et al. (2015); } \\
\text { Djulius (2017); Burakov et al. (2018) }\end{array}$ \\
\hline OPEN & $\begin{array}{c}\text { Trade } \\
\text { openness }\end{array}$ & $\begin{array}{c}\frac{\text { Exports }+ \text { imports }}{G D P} \\
\text { (quarterly frequency) }\end{array}$ & $\begin{array}{l}\text { General Statistics } \\
\text { Office of Vietnam }\end{array}$ & $\begin{array}{c}\text { Asiedu (2002); Abdullah et al. (2006); } \\
\text { Boateng et al. (2015); Djulius (2017); } \\
\text { Burakov et al. (2018) }\end{array}$ \\
\hline GROWTH & $\begin{array}{l}\text { Economic } \\
\text { growth }\end{array}$ & $\begin{array}{c}\% \text { of GDP } \\
\text { (quarterly frequency) }\end{array}$ & $\begin{array}{l}\text { General Statistics } \\
\text { Office of Vietnam }\end{array}$ & $\begin{array}{l}\text { Abdullah et al. (2006); Komuves \& } \\
\text { Ramirez (2014); Burakov et al. (2018); } \\
\text { Ahmed (2018) }\end{array}$ \\
\hline
\end{tabular}

\section{RESEARCH RESULTS}

\subsection{Unit root tests}

The study used the Dickey-Fuller test (Dickey \& Fuller, 1979) to test the stationarity of the data series. According to hypothesis $\mathrm{H} 0$, the data series are not stationary.

Table 2. Unit root test results

Source: Authors' analysis results.

\begin{tabular}{l|c|c|c|c}
\hline \multirow{2}{*}{ Variable } & \multicolumn{2}{|c|}{ Original data series } & $\begin{array}{r}\text { First-order differential } \\
\text { data series }\end{array}$ \\
\cline { 2 - 5 } & Test statistic & Prob. & Test statistic & Prob. \\
\hline FDI & -2.579 & $0.0974^{*}$ & -11.745 & $0.0000^{* * *}$ \\
REER & -0.534 & 0.8853 & -5.093 & $0.0000^{* * *}$ \\
OPEN & -7.157 & $0.0000^{* * *}$ & -11.892 & $0.0000^{* * *}$ \\
\hline GROWTH & -3.399 & $0.0110^{* *}$ & -7.519 & $0.0000^{* * *}$ \\
\hline
\end{tabular}

Note: ${ }^{*},{ }^{* *}$ and ${ }^{* * *}$ indicate significance at the $10 \%, 5 \%$ and $1 \%$ levels, respectively.

Stability test results show that REER variables are not stationary in the original data series. Therefore, the study conducted the first-order differential calculation for all variables, and then tested the sta- tionarity of all first-order differential series. The stationarity test results confirmed that all series were stationary in the first-order differential. Thus, it was decided to use the first-order differential data series to conduct the study.

\subsection{Determining the optimal lag}

Based on the results of testing the optimal lag, the criteria LR and AIC showed that the model has an optimal lag of 3 and a lag of 4 . However, to explain more clearly the relationship between the variables, the study identified the estimation model with a lag of 4 .

\subsection{Cointegration test}

The results of the cointegration test (see Table 3) showed that there was no cointegration in the long term in the data series; therefore, the VAR model is used in the study to examine the relationship between the real effective exchange rate and foreign direct investment in Vietnam, 2005:Q4 - 2019:Q3 (Engle \& Granger, 1987).

Table 3. Determining the optimal lag

Source: Authors' analysis results.

\begin{tabular}{c|c|c|c|c|c|c|c|c}
\hline Lag & LL & LR & Df & P & FPE & AIC & HQIC & SBIC \\
\hline 0 & -622.41 & - & - & - & 547862 & 24.565 & 24.623 & 24.7168 \\
\hline 1 & -595.74 & 53.36 & 16 & 0.000 & 361311 & 24.147 & 24.436 & 24.9041 \\
\hline 2 & -572.98 & 45.51 & 16 & 0.000 & 280709 & 23.882 & 24.403 & 25.2453 \\
\hline 3 & -526.21 & 93.54 & 16 & 0.000 & $86634.6^{*}$ & 22.675 & $23.428^{*}$ & $24.6447^{*}$ \\
\hline 4 & -508.83 & $34.77^{*}$ & 16 & 0.004 & 87126.8 & $22.621^{*}$ & 23.605 & 25.1965 \\
\hline
\end{tabular}


Table 4. Johansen tests for cointegration

Source: Authors' analysis results.

\begin{tabular}{|c|c|c|c|c|c|}
\hline \multicolumn{3}{|c|}{$\begin{array}{l}\text { Trend: constant } \\
\text { Sample: } 5-56\end{array}$} & \multicolumn{3}{|c|}{$\begin{array}{c}\text { Number of obs }=52 \\
\text { Lags }=3\end{array}$} \\
\hline maximum rank & Parms & LL & Eigenvalue & Trace Statistic & $5 \%$ critical value \\
\hline 0 & 36 & -631.2584 & - & 191.5735 & 47.21 \\
\hline 1 & 43 & -573.34014 & 0.89222 & 75.7370 & 29.68 \\
\hline 2 & 48 & -551.48052 & 0.56861 & 32.0178 & 15.41 \\
\hline 3 & 51 & -542.16195 & 0.30121 & 13.3806 & 3.76 \\
\hline 4 & 52 & -535.47163 & 0.22688 & - & - \\
\hline
\end{tabular}

\subsection{Granger causality tests}

Table 5. Granger causality Wald tests

Source: Authors' analysis results.

\begin{tabular}{l|c|c:c:c}
\hline Equation & Excluded & $\mathbf{C h i}^{\mathbf{2}}$ & Df & Pro $\mathbf{~ C h i}$ \\
\hline DFDI & DREER & 8.1887 & 4 & 0.085 \\
\hline DFDI & All & 43.662 & 16 & 0.000 \\
\hdashline DREER & DFDI & 22.132 & 4 & 0.000 \\
\hdashline DREER & All & 56.310 & 16 & 0.000 \\
\hline
\end{tabular}

The results of the Granger Cause Wald test show that REER Granger causes FDI at the 10\% significance level and FDI Granger causes REER at the $1 \%$ significance level.

\subsection{VAR coefficients}

The results of the stability test of the model and the autocorrelation test showed that the VAR model with four lags is stable and appropriate. Testing results of the VAR model show that the real effective exchange rate and FDI have a two-way relationship. This result is consistent with previous studies such as Kosteletou and Liargovas (2000), Shrikhande (2002), Lee (2015), and Tsaurai (2015). At the same time, the research results show that the effective FDI and exchange rate variables were most affected by these factors in the past.

\section{DISCUSSION}

\subsection{The effect of the real effective exchange rate on FDI inflows}

The research results show that DREER (-4) has a positive effect on FDI inflows to Vietnam. This means that VND depreciation increases FDI inflow to Vietnam. The decrease in the value of VND increased the wealth of foreign investors,

Table 6. Testing results of the relationship between REER and FDI

Source: Authors' analysis results.

\begin{tabular}{|c|c|c|c|c|}
\hline \multirow{2}{*}{ Variable } & \multicolumn{2}{|c|}{ DFDI } & \multicolumn{2}{|c|}{ DREER } \\
\hline & Regression coefficient & Significance level & Regression coefficient & Significance level \\
\hline Constant & 120.7961 & 0.101 & 0.572626 & $0.099^{*}$ \\
\hline$D F D I(-1)$ & -0.881523 & $0.000^{* * *}$ & -0.000280 & 0.656 \\
\hline$D F D I(-2)$ & -0.614450 & $0.000^{* * *}$ & -0.00061 & 0.444 \\
\hline DFDI $(-3)$ & -0.387223 & $0.019^{* *}$ & -0.00019 & 0.808 \\
\hline$D F D I(-4)$ & 0.051926 & 0.722 & 0.002307 & $0.001^{* * *}$ \\
\hline $\operatorname{DREER}(-1)$ & 9.531957 & 0.721 & 0.627356 & $0.000^{* * *}$ \\
\hline $\operatorname{DREER}(-2)$ & -3.370857 & 0.905 & 0.030642 & 0.818 \\
\hline $\operatorname{DREER}(-3)$ & -5.318411 & 0.850 & 0.400025 & $0,003^{* * *}$ \\
\hline $\operatorname{DREER}(-4)$ & 75.2034 & $0.006^{* * *}$ & 0.143021 & 0.265 \\
\hline DOPEN $(-1)$ & 277.9706 & 0.297 & 0.953897 & $0.048^{* *}$ \\
\hline DOPEN $(-2)$ & 746.7866 & $0.003^{* * *}$ & 0.176592 & 0.883 \\
\hline DOPEN(-3) & 856.4321 & $0.001^{* * *}$ & 2.676547 & $0.035^{* *}$ \\
\hline DOPEN $(-4)$ & 393.4723 & $0.068^{*}$ & 1.843803 & $0.070^{*}$ \\
\hline DGROWTH(-1) & -167.6555 & 0.127 & 1.840066 & $0.000^{* * *}$ \\
\hline DGROWTH(-2) & 28.3461 & 0.803 & -1.69471 & $0.002^{* * *}$ \\
\hline DGROWTH(-3) & 114.5712 & 0.301 & 0.638595 & 0.222 \\
\hline DGROWTH(-4) & 120.2326 & 0.355 & 0.104307 & 0.865 \\
\hline
\end{tabular}

Note: ${ }^{*},{ }^{* *}$ and ${ }^{* * *}$ indicate significance at the $10 \%, 5 \%$ and $1 \%$ levels, respectively. 


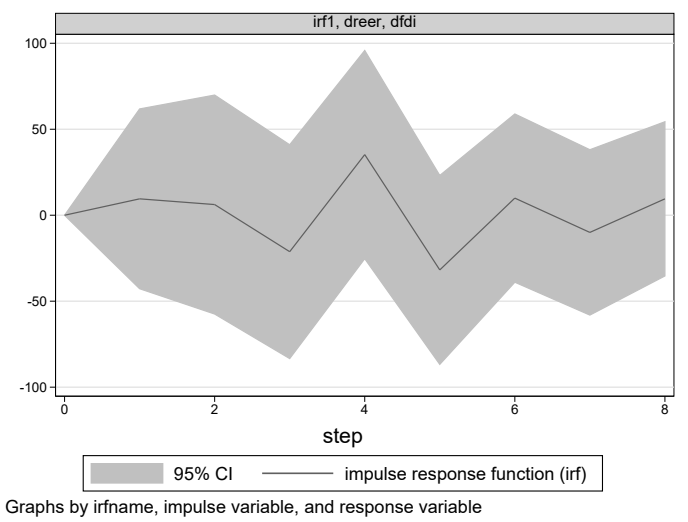

Response of REER to FDI

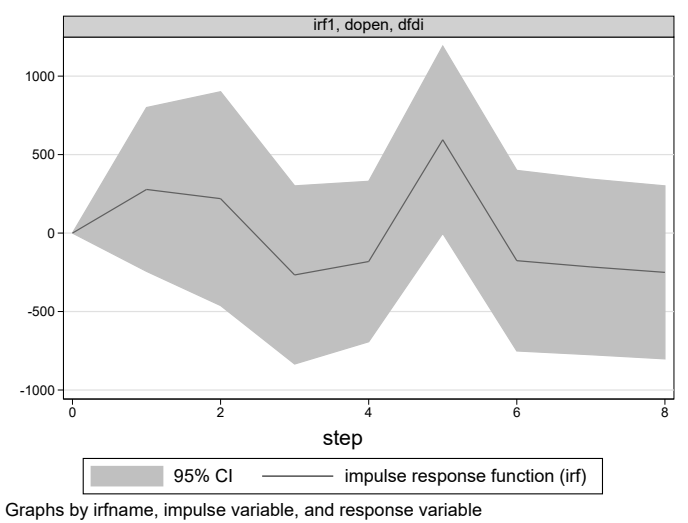

Response of OPEN to FDI

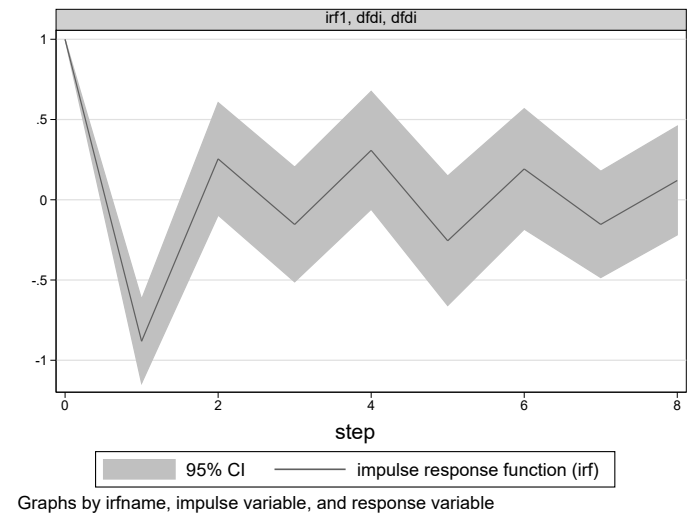

Response of FDI lagged to FDI

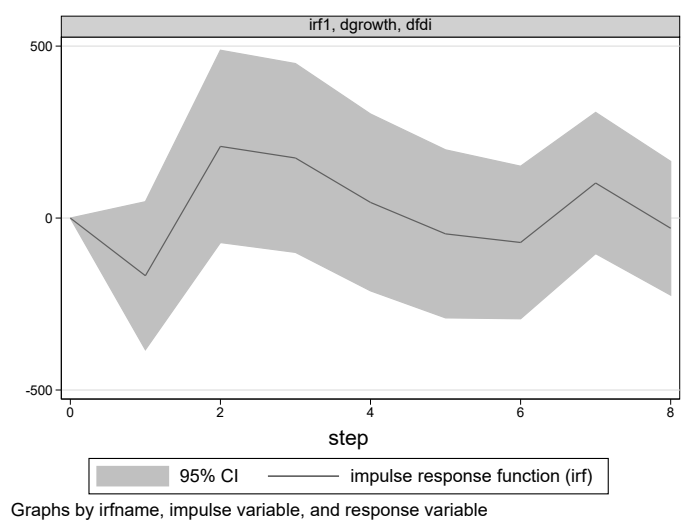

Response of GROWTH to FDI

Figure 1. The response of factors to FDI

making investment costs relatively lower, thus encouraging investment. This effect takes place at the 4-quarter lag (which is a relatively long period of time), which is also consistent with the nature of FDI inflows, which are fixed, decisions related to FDI can only change in the long term. This result is in line with Froot and Stein (1991), Blonigen (1997), Campa et al. (1998), Takagi and Shi (2011), Kodongo and Ojah (2013), Pham and Nguyen (2013), Lee (2015), Tsaurai (2015), and Ibrahim and Raji (2018).

\subsection{The impact of FDI inflows on the real effective exchange rate}

The results show that the increase of FDI in the 4 -quarter lagged increases REER in Vietnam in the period of 2004-2019. Increase in FDI in Vietnam reduces the value of Vietnamese currency. This impact is small but statistically significant and consistent with previous studies, such as Lartey (2011), Jongwanich and Kohpaiboon (2013), Tsaurai (2015), and Aizenman and Binici (2016).

Lartey (2011) argues that an increase in FDI inflows leads to an increase in the value of the host country's currency only in countries with financial openness. According to Lartey (2011), in economies with financial openness, there is a trade-off between resource shifting effect and spending effect after FDI inflows increase. Thus, this result may reflect the fundamental characteristics of Vietnam, with insufficient financial openness.

The chart of FDI and real exchange rates in Vietnam in recent years contributes to illustrating the results of the study. Figure 3 shows the upward trend between the effective exchange rate and FDI in Vietnam. In fact, Vietnamese currency depreciation reduces production costs and asset prices for foreign investors, thus attracting FDI in Vietnam. Moreover, the depreciation 


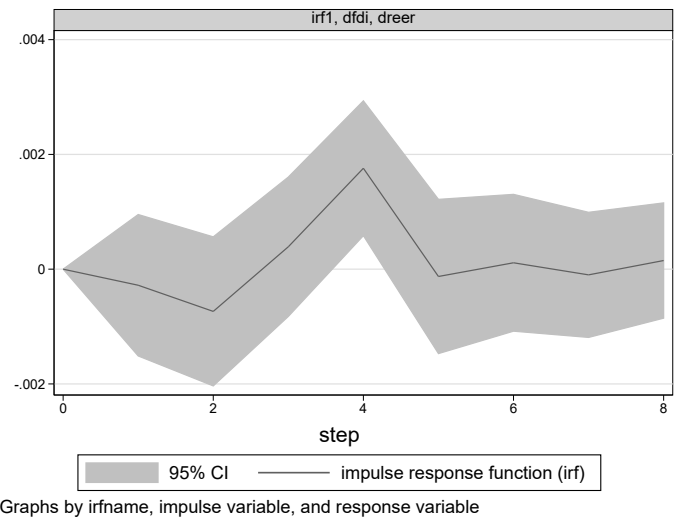

Response of FDI to REER

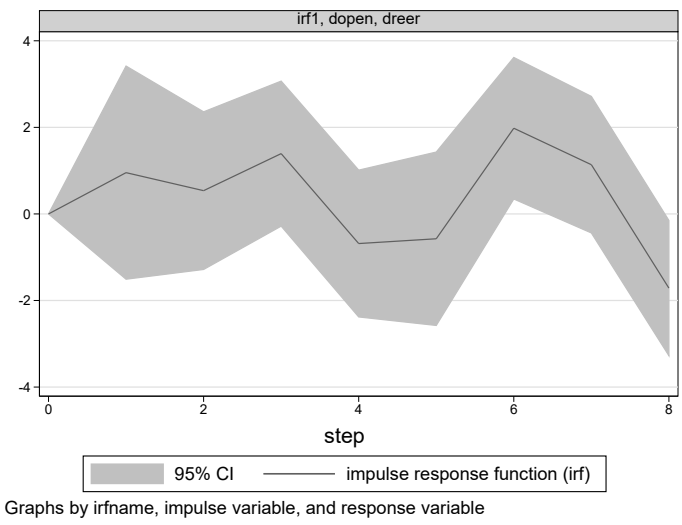

Response of OPEN to REER

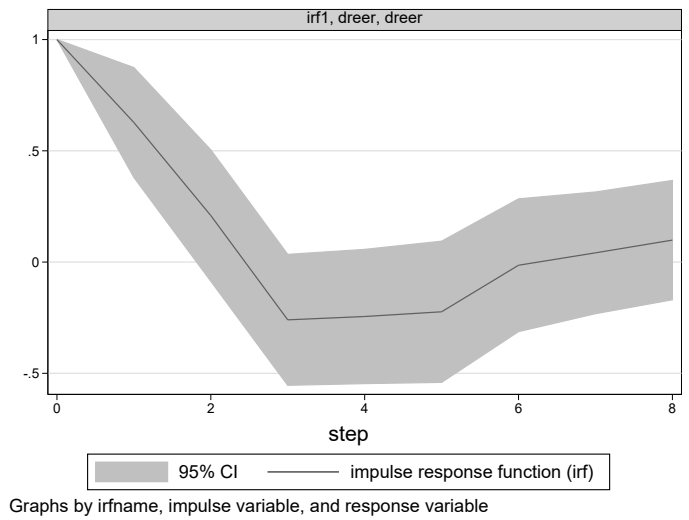

Response of REER lagged to REER

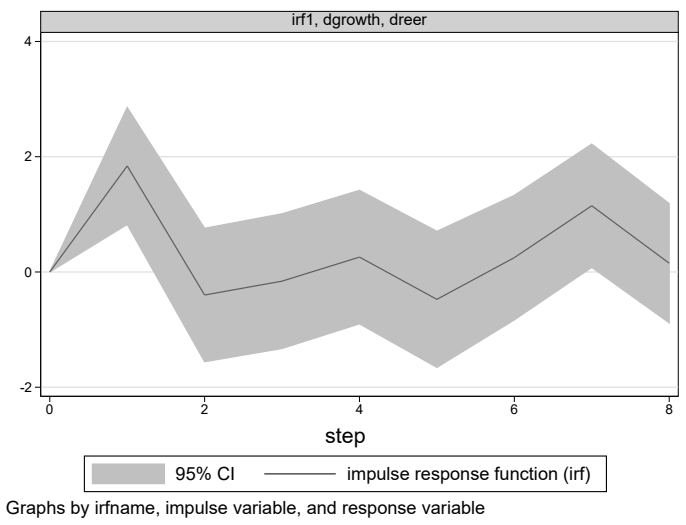

Response of GROWTH to REER

Figure 2. The response of variables to the current REER

of VND compared with trading partners makes goods exported from Vietnam become cheaper for overseas buyers, thus facilitating export businesses. This also attracts many FDI investors to the export-oriented Vietnam. The fact shows that FDI inflows in Vietnam, stimulating/contributing to exports, account for a large proportion of the total export turnover of Vietnam. According to the General Statistics Office of Vietnam (2018), exports from the FDI sector averaged over $66 \%$ of Vietnam's total merchandise exports in the period of 2011-2016. According to data published on the website of the General Statistics Office of Vietnam, exports of foreign invested sector continued to account for an increasing proportion of Vietnam's exports, reaching $72.3 \%$ in $2017,71.7 \%$ in 2018 and $68.8 \%$ in 2019.

In addition, the trade openness factor has a positive impact on the effective exchange rate and FDI. Specifically, the trade openness of DOPEN $(-2)$, DOPEN $(-3)$ and DOPEN $(-4)$ has a positive impact on FDI. Recently, implementing the policy of international integration, Vietnam's economy has a relatively high trade openness and has increased relatively quickly, accompanied by a significant increase in FDI inflows. However, the realistic analysis of the characteristics of the openness of Vietnam's economy still points out many weaknesses. High trade openness and rapid increase are largely due to the large contribution of the FDI sector. Import and export of Vietnam reached the state of trade surplus due to the relative decrease in import. Therefore, in the coming time, the Government should have policies to improve trade openness towards increasing the advantages of trade openness, promoting the internal strength of Vietnam's economy, creating a good foundation for the stability of the economy, continue to increase FDI attraction.

The study also found that economic growth has a small but statistically significant impact on the real effective exchange rate. Economic growth 


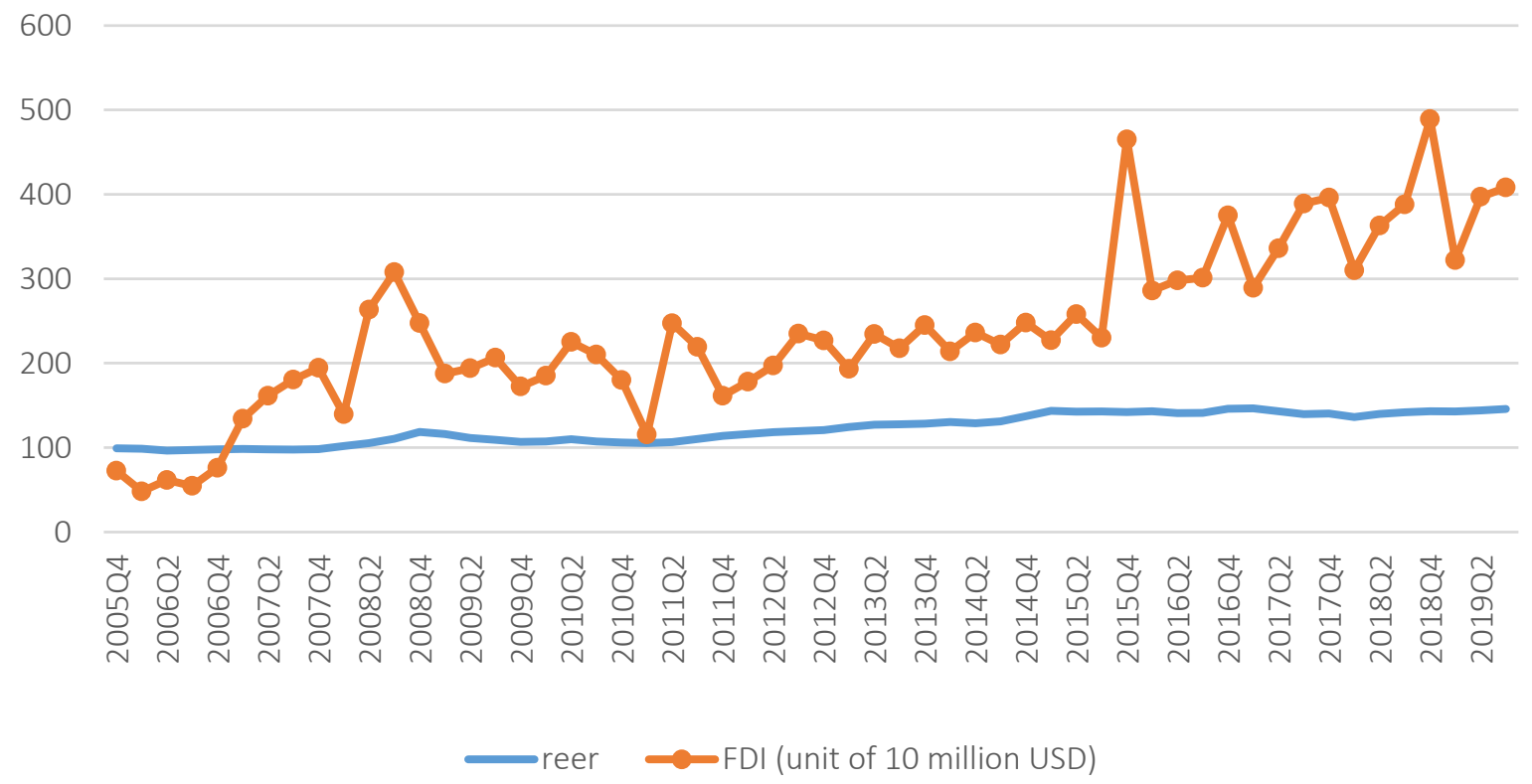

Figure 3. The relationship between REER and FDI inflows in Vietnam

at a 1-period lag has a positive impact on REER. Economic growth at a 2-period lag was found to have a negative effect on the real effective exchange rate. Meanwhile, the study could not reveal a statistically significant impact of economic growth on FDI in Vietnam. Vietnam's economic growth in recent years has remained stable at a high level in recent years (average GDP growth of 6.5\% - 7\%/ year). In the coming time, the Government should continue to stabilize the economy, strive to maintain a high and sustainable growth rate in order to have an impact on FDI attraction.

On the other hand, the study found that past FDI at one- and two-period lags had a negative impact on current FDI. Therefore, the government should control to prevent hot growth of the economy, avoid attracting too much FDI leading to inefficient use allocation. At the same time, the government should select and have policies to promote FDI attraction in areas that can create good premises to attract FDI investors in the future, such as attracting FDI in the field of infrastructure development, especially transport infrastructure for the whole country; FDI attraction focuses on high-tech industries to access advanced technology and strengthen the human resource training of Vietnam.

Test results also show that REER in the past at a 4-period lag has a positive impact on the current REER. According to Combes, Kinda, and Plane (2012), a more flexible exchange rate regime can undermine the appreciation of the real effective exchange rate (derived from the pressure of inflows). Recently, the Central Bank of Vietnam has had effective exchange rate management solutions that need to continue to be promoted: allowing the exchange rate to be more flexible, closely monitoring the movements of the domestic and international foreign currency market (especially the large markets for Vietnam such as the US and China) in order to flexibly manage the exchange rate in the direction of loosening the exchange rate band, allowing the market to adjust itself according to the supply and demand of foreign currencies.

\section{CONCLUSION}

The study used the vector autoregression (VAR) model to test the relationship between exchange rates and FDI in Vietnam for the period 2005-2019. The research found an important empirical evidence on the relationship between the exchange rate and FDI in Vietnam with three key findings. First, there 
is a positive causal relationship between FDI and Vietnam's real effective exchange rate. Second, trade openness has a positive impact on FDI and REER in Vietnam. Third, economic growth has an impact on REER but did not have a statistically significant impact on FDI.

According to the research results, an increase in REER (Vietnamese currency depreciates) will attract more FDI inflows. FDI and REER have been most affected by these factors in the past. Therefore, maintaining a stable exchange rate in the direction of continuous real depreciation will benefit FDI attraction.

At the same time, the research results show that trade openness has a positive impact on FDI and REER. Therefore, it is necessary to pursue policies aimed at improving the quality of trade openness, continuing to increase the number of trade openness, creating a good foundation for exchange rate stability and increasing the attraction of foreign investment.

\section{AUTHOR CONTRIBUTIONS}

Conceptualization: Tram Thi Xuan Huong, My-Linh Thi Nguyen, Nguyen Thi Kim Lien. Data curation: Tram Thi Xuan Huong, My-Linh Thi Nguyen, Nguyen Thi Kim Lien. Formal analysis: Tram Thi Xuan Huong, My-Linh Thi Nguyen, Nguyen Thi Kim Lien. Funding acquisition: Tram Thi Xuan Huong, My-Linh Thi Nguyen, Nguyen Thi Kim Lien. Investigation: Tram Thi Xuan Huong, My-Linh Thi Nguyen, Nguyen Thi Kim Lien. Methodology: Tram Thi Xuan Huong, My-Linh Thi Nguyen, Nguyen Thi Kim Lien. Project administration: Nguyen Thi Kim Lien.

Resources: Tram Thi Xuan Huong, My-Linh Thi Nguyen, Nguyen Thi Kim Lien.

Software: Nguyen Thi Kim Lien.

Supervision: Tram Thi Xuan Huong, My-Linh Thi Nguyen

Validation: Tram Thi Xuan Huong, My-Linh Thi Nguyen

Visualization: Nguyen Thi Kim Lien.

Writing - original draft: Nguyen Thi Kim Lien.

Writing - review \& editing: Tram Thi Xuan Huong, My-Linh Thi Nguyen.

\section{REFERENCES}

1. Abdullah, H., Bakar, N. A. A., \& Hassan, S. (2006). Analysis of FDI Inflows to China From Selected Asean Countries: A Panel Cointegration Approach. Journal of Economic Cooperation and Development, 35(3), 1-28. Retrieved from https://www. semanticscholar.org/paper/Analysis-of-FDI-Inflows-into-Chinafrom-ASEAN-5-A-Hassan-Bakar/ ae6a9d78da06d0eaf26c9084d$68 \mathrm{~b} 0 \mathrm{acdb} 80482 \mathrm{~b} 0$

2. Ahmed, A. (2018). Modelling the Effect of Stock Market Volatility and Exchange Rate Volatility on Foreign Direct Investment in Nigeria: A New Framework Approach. Asian Economic and Financial Review, 8(12), 14821505. http://dx.doi.org/10.18488/ journal.aefr.2018.812.1482.1505
3. Aizenman, J., \& Binici, M. (2016). Exchange market pressure in OECD and emerging economies: Domestic vs. external factors and capital flows in the old and new normal. Journal of International Money and Finance, 66, 65-87. http://dx.doi.org/10.1016/j.jimonfin. 2015.12 .008

4. Alba, J. D., Wang, P., \& Park, D. (2010). The impact of exchange rate on FDI and the interdependence of FDI over time. The Singapore Economic Review, 55(4), 733-747. https://doi. org/10.1142/S0217590810004024

5. Asiedu, E. (2002). On the determinants of foreign direct investment to developing countries: is Africa different? World development, 30(1), 107-119.
https://doi.org/10.1016/S0305750X(01)00100-0

6. Barrell, R., \& Pain, N. (1996). An econometric analysis of US foreign direct investment. The Review of Economics and Statistics, 200-207. http://dx.doi. org/10.2307/2109921

7. Blonigen, Bruce A. (1997). Firm-Specific Assets and the Link between Exchange Rates and Foreign Direct Investment. American Economic Review, 87(3), 447-465. Retrieved from https://www.jstor.org/ stable $/ 2951354$ ? seq $=1$

8. Boateng, A., Hua, X., Nisar, S., $\& \mathrm{Wu}, \mathrm{J}$. (2015). Examining the determinants of inward FDI: Evidence from Norway. Economic Modelling, 47, 118-127. http:// 
dx.doi.org/10.1016/j.econmod.2015.02.018

9. Borensztein, E., De Gregorio, J., \& Lee, J. W. (1998). How does foreign direct investment affect economic growth? Journal of International Economics, 45(1), 115-135. https://doi.org/10.1016/ S0022-1996(97)00033-0

10. Buch, C. M., \& Kleinert, J. (2008). Exchange rates and FDI: goods versus capital market frictions. World Economy, 31(9), 1185-1207. http://dx.doi.org/10.1111/j.14679701.2008.01124.x

11. Burakov, D., Intse, M., \& Freidin, M. (2018). Energy Consumption, Trade Openness and Exchange Rate Impact on Foreign Direct Investment in Union State of Russia and Belarus. International Journal of Energy Economics and Policy, 8(4), 77-82. Retrieved from https://www.researchgate. net/publication/327174461_Energy_Consumption_Trade_Openness_and_Exchange_Rate_Impact_on_Foreign_Direct_Investment_in_Union_State_of_Russia_and_Belarus

12. Campa, J. M. (1993). Entry by foreign firms in the United States under exchange rate uncertainty. The Review of Economics and Statistics, 75(4), 614-622. http://dx.doi. org/10.2307/2110014

13. Combes, J. L., Kinda, T., \& Plane, P. (2012). Capital flows, exchange rate flexibility, and the real exchange rate. Journal of Macroeconomics, 34(4), 1034-1043. http://dx.doi. org/10.1016/j.jmacro.2012.08.001

14. Cushman, D. O. (1985). Real exchange rate risk, expectations, and the level of direct investment. The Review of Economics and Statistics, 67(2), 297-308. http:// dx.doi.org/10.2307/1924729

15. Dickey, D. A., \& Fuller, W. A. (1979). Distribution of the estimators for autoregressive time series with a unit root. Journal of the American Statistical Association, 74(366a), 427-431. http://dx.doi.org/10.1080/016214 59.1979.10482531

16. Djulius, H. (2017). Energy use, trade openness, and exchange rate impact on foreign direct investment in Indonesia. International Journal of Energy Economics and Policy, 7(5), 166-170. Retrieved from https:// www.researchgate.net/publication/321081976_Energy_Use_ Trade_Openness_and_Exchange_ Rate_Impact_on_Foreign_Direct_ Investment_in_Indonesia

17. Dunning, J. H. (1988). The theory of international production. The International Trade Journal, 3(1), 21-66. http://dx.doi. org/10.1080/08853908808523656

18. Engle, R. F., \& Granger, C. W. (1987). Co-integration and error correction: representation, estimation, and testing. Econometrica: Journal of the Econometric Society, 55(2), 251-276. http://dx.doi. org/10.2307/1913236

19. Ersoy, I. (2013). The role of private capital inflows and the exchange market pressure on real exchange rate appreciation: The case of Turkey. South African Journal of Economics, 81(1), 35-51. https://doi.org/10.1111/j.18136982.2012.01330.x

20. Froot, K. A., \& Stein, J. C. (1991). Exchange rates and foreign direct investment: an imperfect capital markets approach. The Quarterly Journal of Economics, 106(4), 1191-1217. https://doi. org/10.2307/2937961

21. General Statistics Office of Vietnam (2018). The 2017 economic census - Result of Foreign Invested Enterprises in the period 2011-2016. Retrieved from http:// www.mpi.gov.vn/en/Pages/tinbai. aspx? idTin $=45803 \&$ id $\mathrm{cm}=109$

22. Ibarra, C. A. (2011). Capital flows and real exchange rate appreciation in Mexico. World Development, 39(12), 2080-2090. http://dx.doi.org/10.1016/j.worlddev.2011.05.020

23. Ibrahim, Y., \& Raji, J. O. (2018). Cross-border merger and acquisition activities in Asia: the role of macroeconomic factors. Studies in Economics and Finance, 35(2), 307-329. https://doi. org/10.1108/SEF-06-2017-0146
24. Ifeakachukwu, N. P., \& Ditimi, A. (2014). Capital inflows and exchange rate in Nigeria. Mediterranean Journal of Social Sciences, 5(7), 263. https://doi. org/10.5901/mjss.2014.v5n7p263

25. Itagaki, T. (1981). The theory of the multinational firm under exchange rate uncertainty. Canadian Journal of Economics, 14(2), 276-297. http://doi. org/10.2307/134798

26. Jongwanich, J., \& Kohpaiboon, A. (2013). Capital flows and real exchange rates in emerging Asian countries. Journal of Asian Economics, 24, 138-146. http:// dx.doi.org/10.1016/j.asieco.2012.10.006

27. Kodongo, O., \& Ojah, K. (2013). Real exchange rates, trade balance and capital flows in Africa. Journal of Economics and Business, 66, 22-46. http://dx.doi.org/10.1016/j. jeconbus.2012.12.002

28. Komuves, Z., \& Ramirez, M. D. (2014). FDI, Exchange Rate, and Economic Growth in Hungary, 1995-2012: Causality and Cointegration Analysis. Applied Econometrics and International Development, 14(1), 45-58.

29. Kosteletou, N., \& Liargovas, P. (2000). Foreign direct investment and real exchange rate interlinkages. Open Economies Review, 11(2), 135-148. https://doi. org/10.1023/A:1008383821669

30. Lartey, E. K. (2011). Financial openness and the Dutch disease. Review of Development Economics, 15(3), 556-568. http:// dx.doi.org/10.1111/j.14679361.2011.00627.x

31. Lee, J. W. (2015). Dynamic Relationships between exchange rates and foreign direct investment: Empirical evidence from Korea. Asian Economic Journal, 29(1), 73-90. http://dx.doi. org/10.1111/asej.12048

32. Linh, N., \& Lien, N. (2020). The impact of real effective exchange rate volatility on trade balance in Vietnam. Accounting, 6(6), 11671172. https://doi.org/10.5267/j. ac.2020.7.001

33. Morande, F. G. (1988). Domestic currency appreciation and 
foreign capital inflows: What comes first? (Chile, 1977-1982). Journal of International Money and Finance, 7, 447-466.

https://doi.org/10.1016/02615606(88)90027-7

34. Pham, T. H. H., \& Nguyen, T. D. (2013). Foreign direct investment, exports and real exchange rate linkages in Vietnam: evidence from a co-integration approach. Journal of Southeast Asian Economies, 250-262. Retrieved from http://citeseerx.ist.psu.edu/ viewdoc/download?doi=10.1.1.45 7.8469\&rep $=$ rep $1 \&$ type $=$ pdf

35. Polat, B., \& Payaslıoğlu, C. (2016). Exchange rate uncertainty and FDI inflows: the case of Turkey. Asia-
Pacific Journal of Accounting \& Economics, 23(1), 112-129. http:// dx.doi.org/10.1080/16081625.20 15.1032312

36. Shrikhande, M. M. (2002). A general equilibrium analysis of foreign direct investment and the real exchange rate. International Journal of Finance \& Economics, 7(4), 309-325. https://doi. org/10.1002/ijfe.194

37. Takagi, S., \& Shi, Z. (2011). Exchange rate movements and foreign direct investment (FDI): Japanese investment in Asia, 1987-2008. Japan and the World Economy, 23(4), 265-272. https://doi.org/10.1016/j.japwor.2011.08.001
38. Tsaurai, K. (2015). FDI location and exchange rates, is there really a relationship between the two? Corporate Ownership and Control, 13(1), 644-653. Retrieved from http://hdl.handle.net/10500/22978

39. Vita, G. D., \& Abbott, A. (2007) Do exchange rates have any impact upon UK inward foreign direct investment? Applied Economics, 39(20), 2553-2564. http://dx.doi. org/10.1080/00036840600749748

40. Yang, J. Y. Y., Groenewold, N., \& Tcha, M. (2000). The determinants of foreign direct investment in Australia. Economic Record, 76(232), 45-54. https://doi. org/10.1111/j.1475-4932.2000. tb00004.x 